\title{
SPEED MEASUREMENT IN AN ACCOMOVING REFERENCE SYSTEM
}

\author{
Volodymyr M. Svishch \\ National Aerospace University "Kharkiv Aviation Institute" \\ 17, Chkalova St., Kharkiv, 61070, Ukraine \\ Corresponding Author: vladimir.svishh@rambler.ru \\ Received February 13, 2020; revised March 2, 2020; accepted March 10, 2020
}

\begin{abstract}
A method of direct measurement of the observer's velocity (peculiar velocity) relative to the accompanying reference system is proposed and investigated. To measure peculiar velocity, it is proposed to use the measurement of stellar light aberration. A comparison of the use of light aberration and the Doppler Effect for measuring velocity relative to relic radiation was made. When using the Doppler Effect, the total speed of the observer was measured - the Hubble speed and the radial component of the peculiar speed of the observer. As a result of the analysis of the components of the observer's velocity in the comoving reference frame, the Hubble and peculiar velocities of the observer, their essential features are formulated. The analysis of the shape of the wave fronts of the CMB radiation, the radiation of quasars, the radiation of stars and the radiation of ground sources is given. As a consequence of this analysis, the decisive influence of the shape of their wave fronts on the possibilities of measuring stellar aberration and the absence of such an effect when measuring velocity using the Doppler Effect are shown. Measurement of light aberration in an inertial system enables direct measurement of the observer's peculiar velocity in an comoving reference frame. Knowing the observer's peculiar velocity is important for increasing the accuracy of determining the Hubble velocity of especially objects of relatively small remoteness. The proposed structures of devices for measuring the peculiar velocity of an inertial reference system were investigated. Peculiar speed is determined by the measured light aberration without switching to another frame of reference. Their expected accuracy and reliability were evaluated. The practical use of the proposed structures is possible in astronomy and spacecraft.
\end{abstract}

KEYWORDS: relict radiation, stellar light aberration, comoving reference frame, Hubble velocity, peculiar velocity, collimator, photo detector.

The measurement of the observer's speed relative to other objects (stars, galaxies, blazars, relict background) is primarily associated with the characteristics of their radiation. The most ancient radiation that can be observed in general in the universe is relict. In accordance with the inflation hypothesis, this residual radiation fills the space of a constantly expanding universe after "separation" from the plasma of the Universe cooled to 3000K about 300,000 years after the Big Bang [1-4]. In fact relict radiation was discovered by Penzias and Wilson in the Laboratory named after Bell in 1964 [5]. In the early 80s with the development of the space industry, it was possible to establish the property of isotropy of relict radiation. In 2006, John Mather and George Smoot were awarded the Nobel Prize in Physics for their discovery of the blackbody shape of the spectrum and the anisotropy of cosmic microwave background radiation.

The results of J. Mather and J. Smoot were confirmation of the origin of the universe as a result of the Big Bang [6-10]. According to the observations of the COBE satellite and the calculations performed, all galaxies and constellations move relative to relict radiation with great speed, about hundreds of kilometers per second.

The measurement of our own velocity relative to relict radiation is an important task in understanding the structure of the Universe.

The temperature of the relict radiation in the direction of the constellation Leo is $0.1 \%$ higher, and in the opposite direction $0.1 \%$ lower [11-13]. This fact is interpreted because of the Doppler effect that occurs when the Sun moves relative to the "motionless" relict background at a speed of about $370 \mathrm{~km} / \mathrm{s}$ towards the constellation Leo. That is, the Doppler shift of the radiation frequency caused by our own speed relative to the reference frame associated with relic radiation. These measurements allow better understanding both the structure of the modern Universe and the early moments of its history $[12,13]$.

Relict radiation is isotropic only in the coordinate system associated with the entire system of scattering galaxies, in the so-called "comoving reference frame", which expands with the Universe. In any other coordinate system, the relict radiation intensity depends on the direction, the so-called dipole component. The comoving reference system is thus distinguished from all other reference systems (a selected reference system - SRS), since only in it the proper, peculiar velocity of the observer and all objects of the universe is directly determined.

By the definition of an comoving reference system, only in it are states possible for a system A with a dipole component of relict radiation equal to 0 in any given point of space. This is the only "absolutely" resting frame of reference - SRS.

$$
v_{\Sigma}=v_{H}+v_{p=0}, v_{H}=0, v_{p}=0 .
$$


Here, $v_{H}$ - hubble velocity component of the total $v_{\Sigma}$ velocity, determined by the expansion of the Universe; $v_{p^{-}}$ peculiar (intrinsic) system A speed.

The vector magnitudes of the velocities, in the SRS are always collinear due to the isotropy of the expansion of space. The collinearity of vectors allows us not to focus on this further when adding or subtracting them.

Measurements from artificial Earth satellites using the Doppler shift of the radiation frequency substantially refined the data of the dipole component [14].

However, the speed of the observer directly affects the observation of extraterrestrial objects. The effect of stellar aberration primarily manifested this influence. The expression of its magnitude directly includes the speed of the observer.

Light aberration was measured only with a relative change in the observer's speed relative to starlight, associated, for example, with the daily rotation of the Earth (daily), with the orbital movement of the Earth around the Sun (annual), of the Sun around the core of the Galaxy (secular). Their measurements are taken, passing from an inertial system with one speed to an inertial system with another speed [15]. These velocities, and the corresponding aberrations, are components of the observer's full, peculiar velocity and the corresponding complete aberration. Since it is not possible to change the completely peculiar velocity, complete aberration $\alpha=\arcsin \frac{v_{p}}{c}$ considers unobservable.

In any closed inertial reference system containing an observer and a radiation source (in a "car"), their mutual position is known. Therefore, if it is possible to measure the aberration of the source in this system, the peculiar velocity $v_{p i}$ of the system is easily determined.

The possibility of measuring the full aberration of light and its observer's own motion velocity hasn't been previously considered.

The study of the possibility of measuring the speed of the observer relative to the selected reference system (SRS) associated with relic radiation, and the possibility of measuring the speed of the inertial reference system (IRS) relative to the SRS without moving to the SRS or any other IRS using full stellar aberration is the goal of this work.

\section{FEATURES OF THE DOPPLER EFFECT AND STELLAR ABERRATION}

We consider the components of the observer's velocity in the SRS $v_{\Sigma}$ taking into account the features of this reference system associated with relic radiation.

Let's distinguish two components of the observer's velocity $v_{\Sigma}, v_{p}$ - the peculiar, intrinsic velocity of the observer relative to the SRS, associated with a change in the position of the observer in space, and $v_{H}$ - the Hubble velocity, associated with the expansion of the space of the Universe (inflationary, gamma) $v_{\Sigma}=v_{H}+v_{p}$.

The peculiar $v_{p}$ and Hubble $v_{H}$ speeds are fundamentally different.

If the observer's own peculiar velocity $v_{p}$ can't exceed the light speed $\mathrm{c}\left(v_{p} \leq c\right)$, then the (inflationary) Hubble expansion speed of space $v_{H}$ can exceed it $c \geq v_{H} \geq c$.

The second fundamental difference: the peculiar velocity $v_{p}$ is oriented in space (anisotropic) and does not depend on the distance of the observer to the beginning of the SRS, and the Hubble speed $v_{H}$ is isotropic in direction (doesn't depend on the direction) and depends on the distance from the object to the beginning of the reference system $v_{H}=$ $H(t) d l$. Hubble speeds $v_{H A}$ of $v_{H B}$ an equidistant from two points observer will be equal in magnitude, and points of space $\mathrm{A}$ and $\mathrm{B}$ located in the same direction will be equal in magnitude, but oppositely directed $v_{H A}=-v_{H B}$.

Because of measuring the Doppler shift of the relic radiation frequency will have common velocities $v_{\Sigma A}=v_{H A}+$ $v_{p A}, v_{\Sigma B}=v_{H B}-v_{p B}, v_{H A}=-v_{H B}$ in opposite directions A, B. Half of the difference in these velocities is equal to the component of the peculiar velocity $v_{p}$ of the observer in the direction $\mathrm{A}, \mathrm{B}$

$$
v_{p A B}=\frac{v_{\Sigma A}-v_{\Sigma B}}{2} .
$$

The maximum of this difference using the Doppler Effect allows you to determine the magnitude and direction of the Earth's own speed relative to the relict radiation. The search for the maximum of this difference is caused by the fact that the Doppler Effect determines the radial velocity directed along the propagation of the light wave.

Unlike the Doppler Effect, stellar aberration depends directly on observer's own speed $v_{p} \alpha=\arcsin \frac{v_{p}}{c}$. Measurement of stellar aberration of relict radiation sources would directly determine the peculiar velocity of the observer $v_{p}=c \sin \alpha$. However, measuring stellar aberration of relict radiation sources is difficult due to its significant features compared to the Doppler Effect.

Let consider the features of stellar aberration and the Doppler Effect as applied to the measurement of the observer's own speed, taking into account the previous analysis of the relict radiation features.

Let choose such stars from the set of stars A and B that their speeds $v_{A}$ and $v_{B}$ are equal in magnitude to observer' speed $v_{n}$ and are multidirectional $v_{n}=v_{A}=-v_{B}$. However, their aberrations are equal $\alpha_{A}=\alpha_{B}=\arcsin \frac{v_{n}}{c}$.

This indicates that:

1) the speed of light $c$ is independent of the speed $v_{A}, v_{B}$ of the source [17];

2) stellar aberration depends on telescopes speed $v_{n}$ relative to the speed of light flux inside the telescope [16]; 
3) stellar aberration is observed in an inertial system $v_{A}=v_{n}$ with a fixed source (star A) and an observer.

Similar conditions exist on the Earth with ground sources. However, stellar aberration of terrestrial sources is not observed.

Let's compare stellar aberration and the Doppler Effect in more detail.

First, stellar aberration does not depend on the source velocity [17]. The Doppler Effect depends on the relative velocity of the source and observer including the Hubble velocity. The Doppler Effect is absent with equal speeds of the observer and the source. That is, in a moving inertial system with a source and an observer, the Doppler Effect is not observed.

Aberration is also observed in a moving inertial system with a fixed source. (An example of a star having a speed equal to the speed of the observer during the radiation of the light flux entering the telescope input at the time of measurement - see above). However, only parts of its components (daily, annual) were measured.

This is because, since the position of the star is unknown, measurements have to be made when moving from one inertial system to an inertial system with another opposite speed. From the measured difference in the positions of the star at opposite speeds, double aberration $2 \alpha_{n}$ is determined. The impossibility of practical independent determination of the position of the star at the time of measurement determines it.

Thus, having a fixed source, with its fixed position relative to the observer, the observer in the inertial system can measure the stellar aberration of the source without switching to another inertial system, as the deviation of the observation pipe from the known position of the source. Using the known aberration of the source $\alpha_{n}$, the observer would determine the speed $v_{n}$ of the inertial system during measurement relative to the light flux of the source without going beyond the inertial system $v_{n}=c \sin \alpha_{n}$.

However, we don't observe the aberration of ground sources.

Stellar aberration depends on the speed of the observer perpendicular to the propagation direction of the light wave of the remote radiation source ("very far from the origin") [17].

The condition of the distance of the radiation source from the observer actually determines the requirements for the wave front shape of the radiation source at the input of the stellar aberration-measuring device. That is, the light wave of a star has a plane wave front. A plane wave is characterized by the fact that the direction of its propagation and the amplitude are the same everywhere [18, 19]. When measuring using the Doppler Effect, such requirements for the shape of the wave front of the source do not arise.

Stellar aberration depends on the speed of the device relative to the propagating light wave in place and while the measuring device is in space (here and now).

Thus, stellar aberration depends on the peculiar velocity of the observer at a given time, at a given point in space and does not depend on its Hubble velocity. This allows determining the component of the current peculiar observer's velocity using the aberration value.

In measurements, using the Doppler Effect, we obtain the sum of the radial, peculiar, and Hubble velocities. The Doppler Effect of stationary ground sources and the observer is absent due to its physical nature. The stellar aberration of terrestrial sources should essentially be observed, but is not observable.

Let us consider the differences between the essential parameters of the radiation of the observed sources during measurements of stellar aberration and the Doppler Effect.

The frequency spectra of the sources are very diverse and their analysis allows you to get rich information about the sources, medium and space that their radiation passed to the observer. To measure speed using the Doppler Effect, the most important parameter is the frequency shift. Stellar aberration is independent of the radiation frequency of the source. Another parameter is the shape of the wave fronts of the sources.

\section{SHAPE OF WAVE FRONTS OF SOURCES}

The shape of the wave fronts does not significantly affect the Doppler Effect, but is very important when observing stellar aberration. The equality of the velocities of the relict radiation, the radiation of distant quasars, the radiation of the stars of our Galaxy and the radiation of ground sources follow based on the independence of the speed of light from the speed of the source and the constancy of its value in vacuum. However, the shapes of their wave fronts are significantly different.

The wave front of radiation of ground-based point sources has a spherical shape of positive curvature $\rho=\frac{1}{R}$, where $\mathrm{R}$ has a finite value. The direction of wave propagation at each point of the wave front coincides with the radius of this point from the center of the sphere at the time of wave emission [18]. The wave front of the emission of stars in our Galaxy is almost flat due to their remoteness $R \approx(4-300000)$ of light years and the curvature of their wave fronts $\rho \approx 0$. The wave front of the radiation of quasars (blazars) is also flat due to their even greater remoteness. Their distance at redshift is $z=(2-20)$. A plane wave differs by the property that its direction of propagation and amplitude are the same everywhere.

Sources of relict radiation are also removed even further. Their remoteness by redshift $z \geq 1000 R \approx \infty$, however, they were extremely specific. Sources of relict radiation are everywhere around us. They scatter in all directions from the observer with a Hubble speed $v_{H}$ significantly exceeding the speed of light $(z \geq 1000)$. The wave front of their 
total radiation is similar to the wave front of a source of radiation of negative curvature $(-\rho \rightarrow-\infty-R \rightarrow 0)$ at the observation point.

Relict radiation is isotropic in all directions. This causes difficulties in increasing the accuracy of determination using the Doppler effect of the direction of the vector of our own velocity relative to the SRS, associated with relic radiation. Measuring aberration relative to relict radiation is impossible because of its isotropy and the curvature of its wave front.

Thus, aberration is not observed in relict radiation $(-\rho \rightarrow-\infty)$, ground-based sources stationary relative to the observer ( $\rho=\frac{1}{R}$ - is the finite value of the spherical wave front) and is observed in stars and blazars (including stars that are stationary relative to the observer, $\rho \approx 0$ - a plane wave front).

That is, when observing a nearby (not remote) source located in the same inertial system with the observer, but having a plane wave front $(\rho \approx 0)$ similar to a stellar one, it becomes possible to measure the aberration of such a source [18]. From the measured aberration of such a source, it is easy to determine the intrinsic speed $v_{p}$ of the inertial system without going beyond this system.

Since the position of the source in the inertial system is known, there is no need to switch to another inertial system, for measure of full light aberration. There is the possibility of prolonged observation of the peculiar velocity of the Earth and its possible changes.

Let consider the possible structures of the peculiar velocity $v_{p}$ meters of an inertial system without going beyond this system, for full aberration measure.

\section{PECULIAR VELOCITY METERS}

The measurement of the observer's own speed is important not only in cosmology. Such measurements are practically important for spacecrafts in deep space exploration. When accelerometers do not work for a long time, in addition to measurement accuracy, the reliability of the device is important. Let consider some measuring instruments of own speed.

The structure of possible peculiar velocity meters consists of blocks $1,2,3$ measuring the velocity $v_{p}$ components installed on the $\mathrm{x}, \mathrm{y}, \mathrm{z}$ axes of the observer's reference frame (Fig. 1). Blocks 1, 2, 3 (Fig. 2) associated with the block 4 of the processing of their output information.

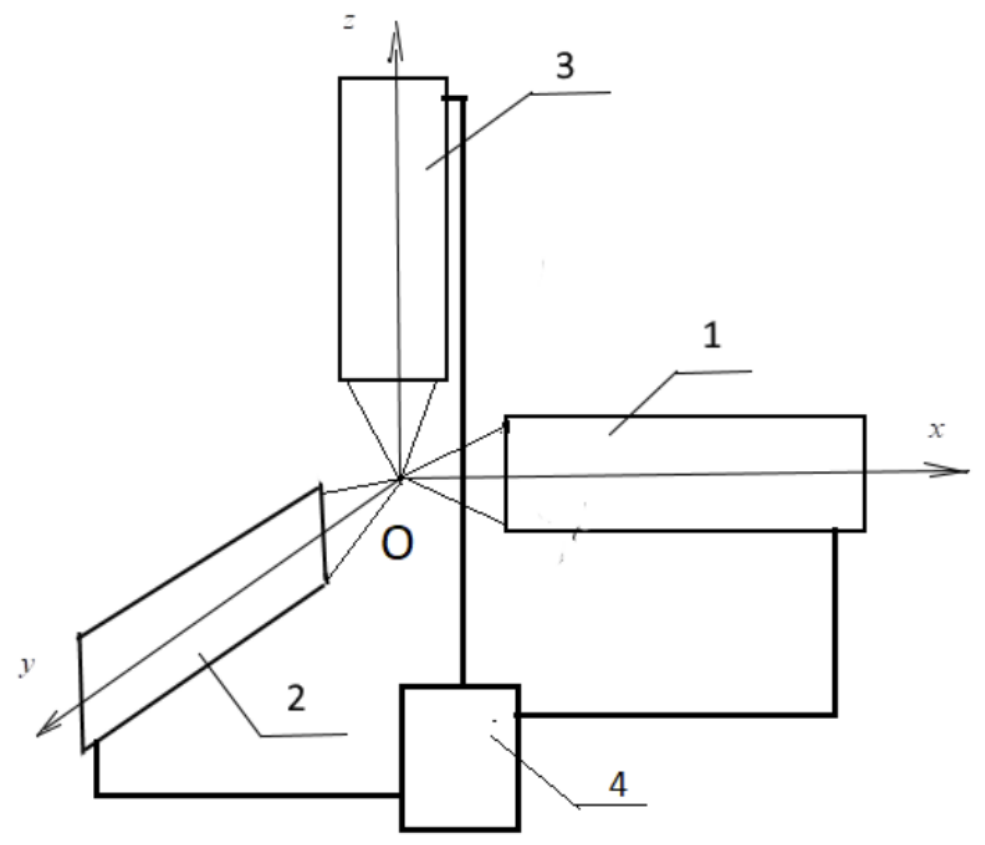

Fig 1. Peculiar velocity meters structure

Meters differ in the used measuring units. The simplest measurement unit 2.1 (Fig. 2) consists of a point radiation source 1 , a collimator 2 , a lens 3 , a body 4 , and a photo detector 5 . The photo detector can be made in the form of a positional sensitive two-dimensional photo matrix or an analog two-dimensional sensitive element.

The photo detector 5 is installed in the perpendicular optical axis of the plane-measuring 2.1 unit with mutually perpendicular directions at a distance from the lens 3. Each measurement unit is mounted on the corresponding axis of the observer's reference system so that the selected directions of their photo detectors coincide with the direction of the axes perpendicular to the installation axis of the measurement unit. To increase the sensitivity, an eyepiece can be installed in front of the photo detector. 
Thus, each photo detector 5 is a two-dimensional screen $s_{z}-x, y ; s_{x}-z, y ; s_{y}-z, x$ with axes perpendicular to the corresponding installation axis of the measuring unit z, x, y (Fig. 3).

The spherical waveform of a point source compensates for the aberration caused by the movement of the device with a ground source [18]. Therefore, when assembling each measurement unit, the relative position of the point source 1, lens 3 and photo detector 5 without collimator 2 is adjusted. The image of source 1 is focused at the beginning of the corresponding coordinates of photodetector 5 . This alignment fixes the location of point source 1, lens 3 and the origin of photo detector 5 on the optical axis of the measurement unit.

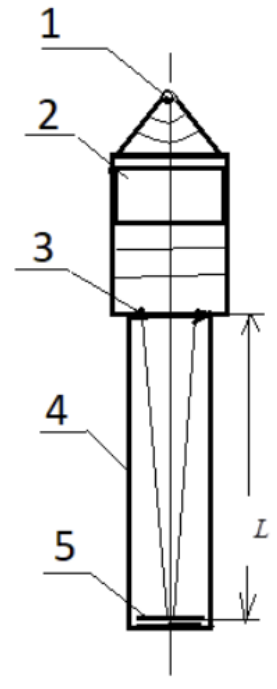

2.1

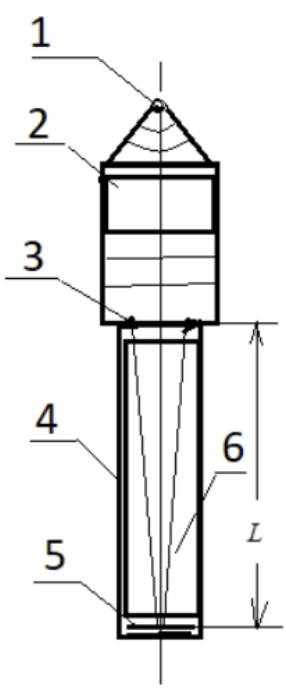

2.2

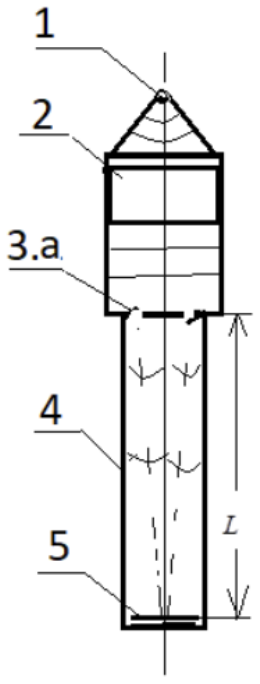

2.3

Fig.2. Measurement blocks 2.1, 2.2, 2.3.

Then, to form a plane wave front perpendicular to the optical axis of the measurement unit, a collimator 2 is installed and the image of source 1 is refocused without reference to the origin of the photo detector 5 . Thus, the conditions for observing a "star" with a known fixed position on the optical axis of each measurement unit are created.
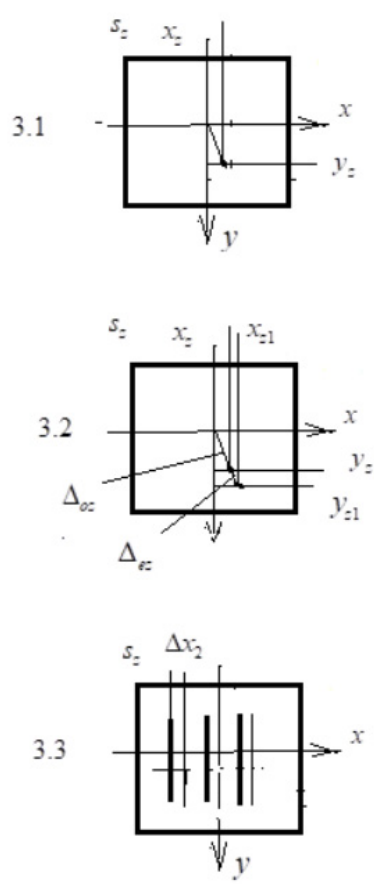
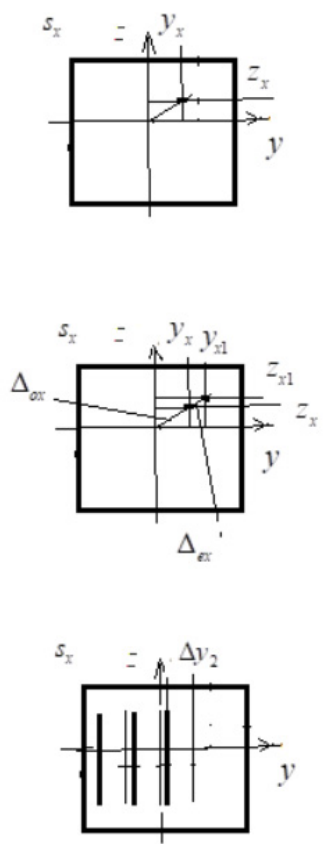
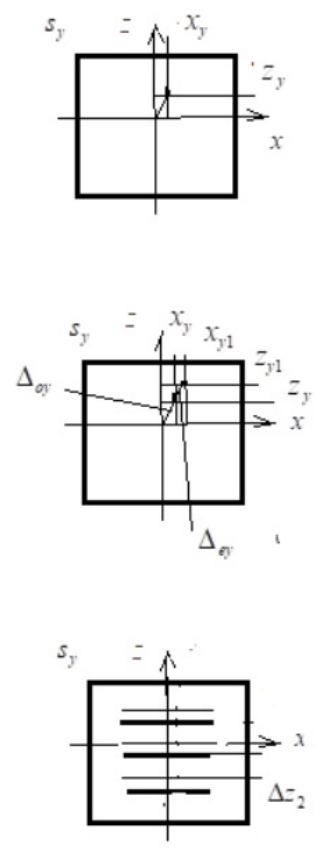

Fig. 3. Measurement screens

After installing the aligned measurement units along the axes $\mathrm{z}, \mathrm{x}, \mathrm{y}$ on the photo detectors $s$ offsets $\Delta_{i}$ from $\Delta_{z}$, $\Delta_{x}, \Delta_{y}$ are proportional to the corresponding velocity $v_{p i}$ component $\Delta_{i p}$. 
As shown in [18], aberration $\propto_{i p}=\frac{v_{i p}}{c} \sin \Psi_{i} \approx \frac{\Delta_{i}}{L}$. Hence, the velocity $v_{p i}$ component $v_{i p}$ is equal to

$$
v_{i p}=\mathrm{c} \frac{\Delta_{i}}{L} \frac{1}{\sin \Psi_{i}}
$$

where $\mathrm{L}$ - is the pipe length of the measuring unit, $\Psi_{i}$ - is the angle between $v_{i p}$ and the axis of the measuring unit.

According to the components $v_{i p}$, projections of the vector of the current peculiar velocity of the meter in the observer's reference system are obtained, proportional $s_{z}-x_{z}, y_{z} ; s_{x}-y_{x}, z_{x} ; s_{y}-x_{y}, z_{y}$ (Fig. 3.1). Projections of the peculiar velocity vector on the axes of the same name $\mathrm{z}, \mathrm{x}, \mathrm{y}$ on different photo detectors should be equal to $x_{z}=x_{y}, y_{z}=y_{x}, z_{x}=z_{y}$. Using these projection values, the processing unit calculates the magnitude and direction of the vector $v_{p i}$ of the current peculiar velocity of the meter in the observer's reference system. Aberration measurements can be made using optically active materials [16]. The refractive indices of an ordinary ray and an extraordinary ray $n_{e} \neq n_{o}$ are different in the direction perpendicular to the optical axis of the uniaxial optically active substance 6 (2.2, Fig. 2). This leads to a difference in the aberration angles of the ordinary and extraordinary ray $\propto_{e}=\frac{n_{o}^{2}}{n_{e}^{2}} \propto_{o}$ and their displacements $\Delta_{o z} \Delta_{o x} \Delta_{o y} \Delta_{e z} \Delta_{e x} \Delta_{e y}$ [16]. Accordingly, the expressions for the projections of the velocity $v_{p i}$ component $v_{i p}$ along the ordinary $v_{\text {oip }}$ and extraordinary $v_{\text {eip }}$ rays will be $v_{o i p}=$ $c \frac{\Delta_{o i}}{L} \frac{1}{\sin \Psi_{i}}$ and $v_{e i p}=c \frac{n_{e}^{2}}{n_{o}^{2}} \frac{\Delta_{e i}}{L} \frac{1}{\sin \Psi_{i}}$, where L is the length of the tube of the measuring unit with an optically active substance.

When using filled with a uniaxial optically active substance with an axis that coincides with the optical axis of the measurement units 2.2 (Fig. 2), they are aligned with the reference to the origin of the photo detectors without collimator 2 using an ordinary ray. Then, a collimator 2 is installed and focusing is again performed without reference to the origin of the photo detector 5. For installed aligned measurement units with optically active substance along the axes $\mathrm{z}, \mathrm{x}, \mathrm{y}$ the photo detectors receive double images of sources 1, according to ordinary $x_{z} x_{y} y_{z} y_{x} z_{x} z_{y}$ and extraordinary $x_{z 1} x_{y 1} y_{z 1} y_{x 1} z_{x 1} z_{y 1}$ rays (Fig. 3.2).

Projections of the current peculiar velocity $v_{\text {oip }}=c \frac{\Delta_{o i}}{L} \frac{1}{\sin \Psi_{i}}$ vector of the meter $s_{z}-x_{z}, y_{z} ; s_{x}-y_{x}, z_{x} ; s_{y}-$ $x_{y}, z_{y}$ correspond to images of a source along an ordinary ray. Images of a source along an extraordinary ray $s_{z}-$ $x_{z 1}, y_{z 1} ; s_{x}-y_{x 1}, z_{x 1} ; s_{y}-x_{y 1}, z_{y 1}$ also correspond to projections of the current peculiar velocity vector $v_{e i p}=$ $c \frac{n_{e}^{2}}{n_{o}^{2}} \frac{\Delta_{e i}}{L} \frac{1}{\sin \Psi_{i}}$.

Here, the difference in the refractive indices of the ordinary and extraordinary rays $n_{e} \neq n_{o}$ in the perpendicular optical axis of the measurement units is taken into account [16]. By these values of the projections, by the ordinary ray $s_{z}-x_{z}, y_{z} ; s_{x}-y_{x}, z_{x} ; s_{y}-x_{y}, z_{y}$ and on an extraordinary ray $s_{z}-x_{z 1}, y_{z 1} ; s_{x}-y_{x 1}, z_{x 1} ; s_{y}-x_{y 1}, z_{y 1}$, the processing unit calculates the magnitude and direction of the vector $v_{p i}$ of the current peculiar speed of the meter on ordinary $v_{\text {oip }}$ and extraordinary $v_{\text {eip }}$ rays. Their values must be equal $v_{\text {oip }}=v_{\text {eip }}$.

To measure the peculiar velocity using a Young's interferometer [18], light sources 1 were installed in the measurement units 2.3 (Fig. 2), in the form of a brightly lit narrow gap. Instead of lenses 3, there are installed screens 3.a with narrow slots parallel to the slit of light source 1 so that the slits of light source 1 and screens are perpendicular to the corresponding axes $\mathrm{x}, \mathrm{y}, \mathrm{z}$ of photo detectors $3.3 s_{z} s_{x} s_{y}$ in the observer's reference frame (Fig. 3).

When adjusting the measurement units, the position of the interference pattern on the photo detectors $S_{z} S_{x} S_{y}$ is fixed. The collimators 2 of the luminous flux of the source 1 are installed in the aligned measurement blocks 2.3 . The collimators 2 provide the output of the luminous flux with a plane wave front parallel to the plane of the screen 3.a.

The interference patterns on the photo detectors $3.3 s_{z} s_{x} s_{y}$ will shift to $\Delta i_{2}=-L_{2} \frac{v_{i p}}{c} \sin \Psi$ in the opposite direction to the corresponding components $v_{i p}$ of the velocity $v_{p i}$. Based on these values $\Delta x_{2} \Delta y_{2} \Delta z_{2}$ projections, the processing unit calculates the components $v_{i p}=\frac{\Delta i_{2}}{L_{2} \sin \Psi} c$ and from them the magnitude and direction of the vector $v_{p i}$ of the current peculiar velocity of the meter [18].

To calculate the current peculiar velocity vector by processing unit 4 (Fig.1), the projection values of the measurement units along any two axes are sufficient. Projection values from the third measurement unit can be used to increase the accuracy and reliability of measurements.

The projection values for an ordinary ray and for an extraordinary ray when using measurement units filled with uniaxial optically active substance 6 (2.2, Fig. 2) can be used to further increase the reliability of measurements. This is especially important when measuring the current speed of vehicles in deep space.

The use of measurement 2.3 (Fig.3) units with a Jung's interferometer makes it possible to measure the velocity $v_{p i}$ component $v_{p i}$ along only one axis in the observer's reference frame. However, the use of a shift in the interference pattern on photodetectors can improve the accuracy of measuring the velocity component. 
In all analysis results, first-order quantities $\frac{v}{c}$ are obtained. The influence of motion (second order $\Delta t, \Delta r$ magnitude $\frac{v^{2}}{c^{2}}$ ) determined by the Lorentz transformations here may not be taken into account when measuring order magnitudes $\frac{v}{c}$.

\section{CONCLUSIONS}

1. Measurement of light aberration in a closed inertial system enables direct measurement of the (peculiar) speed of the observer in a comoving, selected reference system (SRS) without the Hubble component.

2. By measuring the component of the current peculiar velocity vector $v_{H}$ in the selected direction, and by the total speed $v_{\Sigma}$ using the Doppler effect, it is easy to calculate the Hubble speed determined by Universe expansion $v_{H}$ (averaged) by $\mathrm{z} \geq 1000$ in the same direction.

3. The expected accuracy of measuring the speed of the inertial reference system is better for a device with measuring units based on Jung's interferometer.

4. In a device with blocks filled with a uniaxial optically active substance, we obtain double duplication of the measurement channels. This increases the reliability of the devices, which is important when used to track the peculiar speed of the Earth and in spacecrafts for deep research.

\section{ORCID IDs}

(D)Volodymyr M. Svishch, https://orcid.org/0000-0003-2903-5744

\section{REFERENCES}

[1] Ya.B. Zeldovich, Hot model of the Universe. UFN, 89, 647-668 (1966), https://doi.org/10.3367/UFNr.0089.196608e.0647.

[2] Ya.B. Zeldovich and R.A. Syunyaev, Astrophys. Space Sci. 6, 358-376 (1970), https://doi.org/10.1007/BF00653855.

[3] Ya.B. Zeldovich and I.D. Novikov, The structure and evolution of the Universe, (Nauka, Moscow, 1975). (in Russian)

[4] S. Weinberg, The First Three Minutes: A Modern View of the Origin of the Universe, (Basic books, New York, 1977).

[5] A. Penzias, Rev. Mod. Phys. 51, 425 (1979), https://www.nobelprize.org/uploads/2018/06/penzias-lecture.pdf.

[6] J. Silk, The Big Bang. The birth and evolution of the Universe. (Mir, Moscow, 1975), pp. 391. (in Russian)

[7] A.D. Dolgov, Ya.B. Zeldovich and M.V. Sagin, Cosmology of the Early Universe. (MSU, Moscow, 1988), pp. 199. (in Russian)

[8] I.D. Novikov, Evolution of the Universe, (Nauka, Moscow, 1990), pp. 192. (in Russian)

[9] D.I. Novikov, in: Historical Development of Modern Cosmology, ASP Conference Series, 252, edited by V.J. Martínez, V. Trimble and M.J. Pons-Bordería, (ASP Publisher, San Francisco, 2001).

[10] Yu.N. Eroshenko, Physics-Uspekhi, 8, 181 (2011), https://doi.org/10.3367/UFNe.0181.201108c.0858.

[11] R.J. Bouwens, P.A. Oesch, G.D. Illingworth, I. Labbe, P.G. van Dokkum, G. Brammer, D. Magee, L. Spitler, M. Franx, R. Smit, M. Trenti, V. Gonzalez and C.M. Carollo, https://doi.org/10.1088/2041-8205/765/1/L16.

[12] P.J.E. Peebles, Principles of Physical Cosmology, (Princeton University Press, Princeton, 1993), pp. 736.

[13] A. Kovács and J. García-Bellido, Monthly Notices of the Royal Astronomical Society, 462(2), 1882-1893 (2016), https://doi.org/10.1093/mnras/stw1752.

[14] A.V. Zasov and K.A. Postnov, General astrophysics, (Fryazino, 2005), pp. 496. (in Russian)

[15] L.D. Landau and E.M. Lifshits, The theory of field, (Fizmatlit, Moscow, 2003), pp. 534.

[16] V.M. Svishch, East Eur. J. Phys. 4(3), 71-77 (2017), https://doi.org/10.26565/2312-4334-2017-3-10.

[17] A. Einstein, Collection of Transactions Vol.1, (Nauka, Moscow, 1965), pp. 702. (in Russian)

[18] V.M. Svishch, East Eur. J. Phys. 5(3), 24-31 (2018), https://doi.org/10.26565/2312-4334-2018-3-03.

[19] V.M. Svishch, Optics, 7(2), 74-79 (2018), https://doi.org/10.11648/j.optics.20180702.13.

\section{ВИМІРЮВАННЯ ШВИДКОСТІ В СУПУТНІЙ СИСТЕМІ ВІДЛІКУ}

\section{В.М. Свищ}

Харківський національний аерокосмічний університет ім. М.С. Жуковського «Харківський авіаційний інститут» вул. Чкалова 17, Харків, Украӥна, 61070

Запропоновано та досліджено спосіб прямого виміру швидкості спостерігача (пекулярної швидкості) відносно супутньої системи відліку. Для виміру пекулярної швидкості пропонується використовувати вимірювання зіркової аберації світла. Проведено порівняння використання аберації світла та ефекту Допплера для вимірювання швидкості відносно реліктового випромінювання. При використанні ефекту Допплера вимірюється сумарна швидкість спостерігача - хабловська швидкість та радіальна складова пекулярної швидкості спостерігача. В результаті проведеного аналізу складових швидкості спостерігача в супутній системі відліку, хабловської та пекулярної швидкостей спостерігача, сформульовано їх суттєві особливості. Наведено аналіз форми фронтів хвиль реліктового випромінювання, випромінювання квазарів, випромінювання зірок та випромінювання наземних джерел. В наслідок цього аналізу, показано визначальний вплив форми ïx хвильових фронтів на можливості вимірювання зіркової аберації та відсутність такого впливу при вимірюванні швидкості з використанням ефекту Доплера. Вимірювання аберації світла в інерційній системі надає можливість прямого вимірювання пекулярної швидкості спостерігача в супутній системі відліку. Знання пекулярної швидкості спостерігача важливе для підвищення точності визначення хабловської швидкості особливо об'єктів порівняно невеликої віддаленості. Досліджені запропоновані структури пристроїв вимірювання пекулярної швидкості інерційної системи відліку. Пекулярна швидкість визначається по виміренній аберації світла не переходячи до іншої системи відліку. Виконано оцінку їх очікуваної точності 
та надійності. Практичне використання пропонованих структур можливе в астрономії та апаратах дослідження далекого космосу.

КЛЮЧОВІ СЛОВА: реліктове випромінювання, зіркова аберація світла, система відліку, хабловська швидкість, пекулярна швидкість, коліматор, фотоприймач.

\section{ИЗМЕРЕНИЕ СКОРОСТИ В СОПУТСТВУЮЩЕЙ СИСТЕМЕ ОТСЧЕТА}

\section{В.М. Свиш}

Харьковский национальный аэрокосмический университет им. М.Е. Жуковского «Харьковский авиационный институт» Харьков, Украина, 61070

Предложен и исследован способ прямого измерения скорости наблюдателя (пекулярной скорости) относительно сопутствующей системы отсчёта. Для измерения пекулярной скорости предлагается использовать измерение звездной аберрации света. Проведено сравнение использования аберрации света и эффекта Доплера для измерения_скорости относительно реликтового излучения. При использовании эффекта Доплера измеряется суммарная скорость наблюдателя хабловская скорость и радиальная составляющая пекулярной скорости наблюдателя. В результате проведенного анализа составляющих скорости наблюдателя в сопутствующей системе отсчёта, хабловской и пекулярной скоростей наблюдателя, сформулированы их существенные особенности. Приведен анализ формы волновых фронтов реликтового излучения, излучения квазаров, излучения звезд и излучения наземных источников. Вследствие этого анализа, показано определяющее влияние формы их волновых фронтов на возможности измерения звездной аберрации и отсутствие такого влияния при измерении скорости с использованием эффекта Доплера. Измерение аберрации света в инерциальной системе дает возможность прямого измерения пекулярной скорости наблюдателя в сопутствующей системе отсчёта. Знание пекулярной скорости наблюдателя важно для повышения точности определения хабловской скорости особенно объектов сравнительно небольшой удаленности. Исследованы предложенные структуры устройств измерения пекулярной скорости инерциальной системы отсчета. Пекулярная скорость определяется по измеренной аберрации света без перехода в другую систему отсчёта. Оценена их ожидаемая точность и надежность. Практическое использование предложенных структур возможно в астрономии и аппаратах для исследования дальнего космоса.

КЛЮЧЕВЫЕ СЛОВА: реликтовое излучение, звездная аберрация света, система отсчёта, хабловская скорость, пекулярная скорость, коллиматор, фотоприемник. 